\title{
SEX OFFENSES: THE AMERICAN LEGAL CONTEXT
}

\author{
MORRIS Ploscowe*
}

A rational code of sex offense laws is long overdue in this country. Sex offense legislation presently on the books is largely unenforceable and much of this legislation does a great deal more harm than good. There are a number of fundamental reasons for this. In the first place, the prohibitions imposed by these laws are far too inclusive, covering far too many areas of sexual behavior. These laws make potential criminals of most of the adolescent and adult population, in that they proscribe every conceivable sexual act except a normal act of coitus between a man and a woman who are married to each other or an act of solitary masturbation. They, of course, prohibit not only the more innocuous kinds of sexual behavior engaged in by normal adults and adolescents, but also aberrant sexual behavior that may be dangerous. Thus, not only heavy necking, mutual masturbation, fornication, and adultery, but also forcible rape, forcible sodomy, incest, and the sexual abuse of small children are interdicted by these laws.

One goal of sex offense laws is to keep individuals chaste before marriage. Until then, individuals must not give overt expression to any sexual desires, except possibly through solitary masturbation; sex drives must be kept in check, under pain of incarceration.

After marriage, too, the law attempts to confine sexual activity. Thus, a married individual may not look for sexual liaison with other than his or her spouse, however embittered or distasteful their relations may have become. And should his or her spouse be in jail, in the country or overseas, or living separate and apart, a married individual must figuratively fasten on a chastity belt. Adultery may open the door to the penitentiary.

Nor is adultery the only invitation to sanctions for married individuals. Since time immemorial, men and women have engaged in what are politely called aberrant sex practices; nor are many of them-for example, oral-genital contacts-the exclusive usages of homosexuals and lesbians, but commonly may be indulged in a normal marital relationship. Indeed, most modern marriage manuals no longer view such practices with alarm as perversions, but rather consider them to be permissible preludes to normal coitus. The law, however, usually takes a different view and subjects participants in such acts to a possible felony conviction.

When American sex offense legislation is compared with the analogous law of Tudor England, one cannot but conclude that the modern American is considerably

* A.B. I925, LL.B. I93I, Harvard University. Member of the New"York bar; Adjunct Associate Professor of Law, New York University; Associate Reporter, American Law Institute, Model Penal Code. New York City Magistrate, I945-53. Author, Sex aNd The Law (I95I), The TruTh Abour Drvorcè (1955), and other publications. 
more naive than were his English ancestors. Only a small part of the sexual behavior legally proscribed here today was prohibited by the criminal law of Tudor England. Forcible rape, sexual intercourse with a female under ten, the sexual corruption of children, lewd and indecent acts in public, bestiality, buggery, the maintenance of houses of prostitution, too, might be punishable under the old English criminal law; but large areas of sexual behavior-for example, fornication, adultery, incest, fellatio, cunnilingus, mutual masturbation-were beyond the reach of the law and were punishable only as sins or ecclesiastical offenses by the Church of England. Since the ecclesiastical courts were not received in this country, our laws, therefore, initially provided no institutionalized means for dealing with sexual behavior that had been ignored by the common law. But the lacunae did not long remain, for legislators, prodded by moralistic constituents, rushed to fill these gaps. And, as we have seen, they have succeeded only too well.

It was apparent to most serious observers long before the Kinsey studies ${ }^{1}$ that our sex offense laws were honored more in the breach than in the observance. Few branches of the law have shown such a wide divergence between actual human behavior and stated legal norms. Nor should this be surprising. Sexuality simply cannot realistically be confined within present legal bounds. It does not mysteriously blossom when a man and a woman are united in holy matrimony; nor, despite legal prohibitions, is it thereafter restricted to conventional acts of coition between marital partners.

The wide-ranging character of the prohibitions of sex offense laws and the almost universal disregard that they are accorded elicited the following biting comment and criticism from Dr. Kinsey: ${ }^{2}$

All of these and still other types of sexual behavior are illicit activities, each performance of which is punishable as a crime under the law. The persons involved in these activities, taken as a whole, constitute more than 95 per cent of the total male population. Only a relatively small proportion of the males who are sent to penal institutions for sex offenses have been involved in behavior which is materially different from the behavior of most of the males in the population. But it is the total 95 per cent of the male population for which the judge or board of public safety, or church, or civic group demands apprehension, arrest, and conviction, when they call for a clean-up of the sex offenders in a community. It is, in fine, a proposal that 5 per cent of the population should support the other 95 per cent in penal institutions.

The writer has pointed out elsewhere ${ }^{3}$ that this conclusion that ninety-five per cent of the male population could be jailed because of violations of sex offense laws is an exaggeration. It presupposes that such legislation is uniform throughout the country, that all sexual activity except solitary masturbation and normal marital

\footnotetext{
${ }^{2}$ Alfred C. Kinsey, Wardell Pomeroy \& Clyde E. Martin, Sexunl Behavior in the Human Male (r948); Alfred C. Kinsey, Wardell B. Pomeroy, Clyde E. Martin \& Pauz H. Gedhard, Sexual Behavior in the Hunan female (1953).

${ }^{2}$ Alfred C. Kinsey, Wardeli B. Pomeroy \& Clyde E. Martin, Sexual Behavior in the Human MALE 392 (I948). (Emphasis added.)

3 Morris Ploscowe, Sex and the LAw 137 (1951).
} 
intercourse is universally prohibited, and that these laws invariably prescribe jail and prison sentences for their violation. This, however, is not so. One of the most remarkable features of American sex offense laws is their wide disparity in types. of sexual behavior prohibited and their extraordinary variation in penalties imposed for similar offenses.

Fornication, a common form of premarital sexual activity, is prohibited by a majority of state laws; but it is deemed only a meretricious transaction in many states $^{4}$ and is there beyond the reach of police, prosecuting attorneys, and jailers. ${ }^{5}$ Where fornication is prohibited, penalties provided by law vary from a ten-dollar fine in Rhode Island ${ }^{6}$ to a three-year prison sentence in Arizona. ${ }^{7}$

Adultery is more widely prohibited than fornication, although the prohibition is by no means universal. ${ }^{8}$ But among the states that do prohibit it, the same kinds. of sexual misbehavior are not necessarily encompassed. In some states, a single act of coitus between a married individual and one who is not his or her spouse constitutes culpable adultery $;^{\circ}$ in others, however, the adultery must be "open and notorious" or "habitual" before the criminal statute is deemed violated. 10 In some states, an unmarried party to such a connection is deemed to be guilty of adultery; ${ }^{11}$ in others, however, he or she would seem to be guilty of no more than fornication.

Generally, penalties for adultery are more severe than those for fornication, but they also vary considerably. Some states impose no penalties of imprisonment for adultery and make this offense punishable only by a fine; ${ }^{12}$ in others, however, penalties of up to five years of imprisonment may be meted out for this offense. ${ }^{13}$

The crime of rape also differs greatly among the several states. In all states, it embraces much more than the forcible violation of the sexual integrity of a female, including as well conduct to which the female may have consented. In this latter

\footnotetext{
'See, e.g., Rachel v. State, 7 I Okla. Cr. 33, I07 P.2d 813 (I940).

'In at least ro states-Louisiana, Michigan, Missouri, New Mexico, New York, Oklahoma, South. Dakota, Tennessee, Vermont, and Washington-fornication is not statutorily proscribed.

'R. I. Gen. Laws ANn. \$ Ix-6-3 (1956).

${ }^{T}$ Ariz. Rev. Stat. ANn. $\$ 13-222$ (1956). For a summary survey of the penalties imposed by the fornication statutes of the several states, see Robert VeIt SHerwin, SEX aNd tHe Statutory Law pt. I, chart 5 , at 83 (1949).

${ }^{8}$ In at least five states-Arkansas, Louisiana, Nevada, New Mexico, and Tennessee-adultery is not statutorily proscribed.

'See, e.g., People v. Reed, 246 App. Div. 895 (N.Y. 4th Dep't 1936).

${ }^{10}$ See, e.g., Warner v. State, 202 Ind. $479,483,175$ N.E. 661,663 (r933): “. . . it is well settled that our present statute does not prohibit ... acts 'of adulterous intercourse ... of an occasional character, unaccompanied by any pretense of the parties living together.' . . The design of this law is not to affix a penalty for the violation of the Seventh Commandment, but to punish those who, without lawful marriage, live together in the manner of husband and wife." Cf. State v. Chandler, 132 Mo. I55, 33 S.W. 797 (1896).

${ }^{11}$ E.g., N.Y. PeN. Law $\$ 100$.

12 These fines range from a minimum of $\$ 10$ in Maryland, Mp. ANN. ConE art. 27, $\$ 4$ (1957); to a possible maximum of $\$ 2,000$ in Michigan. Мrch. CoMp. LAws $\$ \$ 750.30,750.503$ (1948).

${ }^{13}$ E.g., Conn. Gen. Stat. Rev. \$ 53-218 (1958); Me. Rev. Stat. Ann. ch. 134, § I (1954); Okis. SrAT. tit. $2 x, \$ 872$ (1951); S.D. CODE \$ 3892 (1939); VT. STAT. tit. I3, ch. 5, $\$$ 201 (r958). For $a$ summary survey of the penalties imposed by the adultery statutes of the several states, see SHERwIN, op. cit. stipra note 7 , pt. 1 , chart 7 , at 85 .
} 
connection, it should be noted that the age over which a female is regarded capable of consenting to coitus varies widely. The common-law age of consent of ten years has been discarded by modern statutes. An age limit of sixteen or eighteen years is now most common, although some states place it as low as twelve years, ${ }^{14}$ and another, going to the other extreme, places it at twenty-one years. ${ }^{15}$

Other differences in the definition of rape and in the scope of its statutory prohibition may also be noted. In some states, the lack of chastity of an underage female may be a defense to the charge of rape; ${ }^{16}$ in others, however, a conviction may still be had even if she was operating as a prostitute. ${ }^{17}$ Some states, also, make allowance for the age of the male, ${ }^{18}$ but most statutes are silent on this point. Moreover, in addition to such wide substantive differences as these among the several states as to what constitutes rape, there is also considerable disparity as to penalties. Death or life imprisonment may await a rapist in some states; other states, however, taking a more charitable view of his dereliction, may impose varying terms of imprisonment. ${ }^{19}$

Modern crime-against-nature and sodomy statutes and those interdicting lewd and lascivious behavior include most deviate sexual activity within the scope of their prohibitions. Nevertheless, there are differences here, too, among the several states, especially in the treatment of mutual male masturbation. This conduct is prohibited in many states, whether it occurs publicly or privately; in some, however, it is prohibited only if it occurs in a public place. ${ }^{20}$ Penalties under sodomy and crimeagainst-nature statutes vary enormously as well. Thus, a consensual homosexual act between adults is only a misdemeanor in New York; ${ }^{21}$ but it may be punishable by life imprisonment in some states, ${ }^{22}$ a five-year minimum imprisonment in others, ${ }^{23}$ and a five-year maximum imprisonment in still others. ${ }^{24}$

Even the age-old offense of prostitution shows considerable variation in treatment. Most statutes define prostitution as the indiscriminate offer by a female of her body for sexual intercourse or other lewdness, for the purpose of gain or hire; but in many states, indiscriminate and promiscuous sexual intercourse, even without gain

14 E.g., Ala. Code tit. I4, $\$ 398$ (I940); LA. Rev. Stat. $\$$ I4:41 (1950).

${ }^{16}$ E.g., Tenn. Code ANN. \$ 39-3706 (1955).

${ }^{10}$ E.g., N.C. Gen. Stat. $\$$ 4-26 (1953); TeNN. Code ANN. \$39-3706 (r955); W. VA. Code ch. 61, art. $2, \$ 15$ (I93I).

${ }^{17}$ See, e.g., State v. Snow, 252 S.W. 629 (Mo. Sup. Ct. I923).

${ }^{18}$ E.g., N.Y. PEN. LAW $\$ 2010 ;$ S.C. CODE $\$ \operatorname{IIIY~(1952).~}$

${ }^{10}$ For a summary survey of the penalties imposed by the rape statutes of the several states, see SHERWIN, op. cit. supra note 7 , pt. I, chart 5 , at 85 .

${ }^{20}$ E.g., N.Y. PEN. LAW $\$ 722(8)$.

${ }^{21}$ Id. \$ 690 .

${ }^{22}$ E.g., Nev. Rev. Stat. $\$ 201 . x 90$ (1958); Mrch. Comp. Laws $\$ 750.158$ (1948).

${ }^{23}$ E.g., Ariz. Rev. Stat. ANn. \$ 13-65I (1956); Idaho Code Ann. \$ I8-6605 (1948); Mont. Cơdes REv. ANN. \$ 94-4118 (I947); N.C. GEN. STAT. \$ I4-I77 (1943); TENN. CODE ANN. \$39-707 (1956).

${ }^{24}$ E.g., Kr. Rev. Stat. \$ 436:050 (1955); La. Rev. Stat. \$ 14:89 (1950); N.H. Rev. Stat. ANn, 5. 579:9 (1955); WIs. STAT. $\$ 944.17$ (1957). For a" summary survey of the penalties imposed by the sodomy statutes of the several states, see SHerwis, op. cit. supro note 7, pt. 1, chart 4 , at 82 . 
or hire, may be prostitution. ${ }^{25}$ Many states, moreover, make it possible to punish the customers of prostitutes, as well, either directly by specific statutory provisions ${ }^{26}$ or indirectly by an extension of aiding-and-abetting statutes; ${ }^{27}$ but other states refuse to punish customers, even though there can be no prostitution without them. While prostitutes are generally punishable by imprisonment of less than one year, there are notable exceptions, with maximum sentences running from thirty days ${ }^{28}$ to five years. ${ }^{20}$

The fact that sex offender laws vary so widely among the several states and value judgments as to the danger of similar offenses differ so greatly (as reflected in the range of penalties imposed) is a compelling reason for framing a rational uniform code in this area. We are not a congeries of individual states, each isolated within a water-tight compartment. Modern means of transportation and communication have made state boundaries largely meaningless. American men and women are continually upon the move. They should not be exposed to the risk of being branded felons in one state for sexual behavior that may be legally innocuous in another. They should not be subjected to the possibility of long prison sentences or even death in some states for behavior that may be punishable by only fines or short jail sentences in others, or not even punishable at all. The time has come when the lawyers should attempt to bring some order out of the chaotic profusion and variec, of sex offender laws that now obtains.

The revision of sex offender laws, however, will require much more than the mere elimination of disparities and differences among the several states; it must also consider the fact that many of the existing prohibitions, no matter how widespread, are inherently unenforceable and should be abandoned. Police and prosecuting officials may successfully investigate and prosecute criminal cases where a victim makes a complaint or where the criminal activity is more or less overt in character. But sexual activity is largely private. There is no victim to make a complaint in the ordinary case of fornication, adultery, or deviant heterosexual or homosexual activity. Despite criminal sanctions, therefore, sexual misbehavior of this sort, when carried on privately and discreetly, is practically never punished. It is only the rare unfortunate offender who comes to the attention of the authorities; and although he is no more guilty than the hundreds of thousands of others who have freely indulged in similar kinds of sexual activity, he is pilloried because he was caught. Should police and prosecuting officials be burdened with enforcing such laws against such offenders?

A rational code of sex offender laws would, moreover, basically revise some of our

${ }^{20}$ E.g., Conn. Gen. Stat. Rev. \$53-226 (I958); Del. Code Ann. tit. II, \$ 73 I (I953); Fla. Stat. $\$ 796.07$ (Supp. 1959); N.C. Gen. Stat. \$ I4-203 (I953); Tex. Pen. Code art. 607(20) (I948); Wyo. Comp. Stat. ANn. \$ 9-508 (I945).

${ }^{20}$ E.g., Conn. Gen. Stat. Rev. $\$ 53-231$ (I958); Ill. Rev. Stat. ch. 38, $\$$ I62 (1957); Ind. Ann. Stat. § 10-4219 (1956); Wyo. Comp. Stat. AnN. \$ 9-517 (1945).

${ }^{27}$ Cf. State v. Rayburn, I70 Iowa 514, 153 N.W. 59 (1915).

${ }^{28}$ E.g., Ind. Ann. Stat. $\$$ I0-4220 (I956); Wyo. Comp. Stat. AnN. $\$ 9-518$ (1945).

${ }^{20}$ E.g., Iowa CODE $\S 724.1$ (1958). For a summary survey of the penalties imposed by the prostitution statutes of the several states, see SHeRwiN, op. cit. supra note 7, pt. 2 , chart $4 \mathrm{~A}$, at 68 . 
present concepts in this area. Thus, for example, although force, violence, and overpowering of the will of a female by violence, threat, or fear of bodily harm would continue to be the core of the crime of rape, it is to be hoped that the new formulation would not comprehend those cases where a man may have used considerable effort to persuade a woman to engage in coitus with him, where this was the normal and expected outcome of their association together. Moreover, since most rape convictions involve consensual acts of coitus with young girls, with no element of force or violence, it has long been apparent that the legal age of consent must be reduced. Many girls of fifteen, sixteen, and seventeen years of age voluntarily enter sexual relations with men and boys. Each such sexual contact may technically be rape under some law and may subject the male involved to ferocious penalties, although except for the age of the girl involved, the act may be no different than fornication.

At common law, the lack of appreciation and understanding by a child under ten years of the nature and quality of the sexual act-and her consequent inability to consent to it-was justifiably assimilated to the force and violence and overpowering of the will in the traditional definition of the crime of rape. In our desire to shield young women from sexual experience, we have extended the age limits upward. It is absurd in our culture, however, to talk of young women of middle or late adolescence not having knowledge and appreciation of the sexual act. Such knowledge is usually acquired by the time of puberty. The law should, accordingly, take a more realistic view and fix the age of consent at fourteen years, instead of the higher limits that are more commonly found. Should the legislator wish to protect the morals of young women over fourteen years of age, this can be done by means other than branding as a rapist every male who may dally with them.

But whether or not the age of consent is reduced, it is imperative that the lack of chastity of the young woman be deemed a defense to a charge of statutory rape. It is ridiculous for the police to charge with rape every male who may have had sexual contact with a promiscuous young woman or a young prostitute. The law should, moreover, take into account the age of the male involved in defining this offense. Boys and girls of similar ages engage in many forms of sex activity, and if this leads to coitus, the boy should not necessarily be exposed to penal sanctions.

Also vitally essential in any revision of sex offender laws is a reconsideration of the evidentiary rules, so as to minimize the possibility of convicting innocent defendants. Complaints of sex offenses are easily made. They spring from a variety of motives and reasons. The psychiatrist and the psychoanalyst would have a field day were he to examine all complaints of rape, sexual tampering with children, incest, homosexual behavior with young boys, deviant sex behavior, etc., in any given community. He would find that complaints are too often made of sexual misbehavior that has occurred only in the overripe fantasies of the so-called victims. Frequently, the more or less unconscious wish for the sexual experience is converted into the 
experience itself. Sometimes, too, the so-called victim will charge not the one with whom he or she has had the sexual experience, but someone else who is entirely innocent. Prosecuting attorneys must continually be on guard for the charge of sex offense brought by the spurned female that has as its underlying basis a desire for revenge, or a blackmail or shakedown scheme.

Where the law permits, as it does with respect to many sex offenses, a conviction on the uncorroborated testimony of a complainant, it puts a premium on unfounded complaints. There is no barrier against convicting the innocent, except the good sense of prosecuting attorneys, courts, and jurors. But the moral indignation that is stirred up by a recital of dastardly behavior apparently often overrides good sense, and as a result, far too many men have been railroaded on sex offense charges. Accordingly, no conviction on a sex offense charge should be had where the testimony of the so-called victim is not corroborated by "other material evidence." It is true that such a requirement may result in guilty men escaping just punishment in cases where other evidence is not available. But the dangers involved to innocence where the law makes it possible to imprison a man on the uncorroborated testimony of a disturbed child or spiteful woman outweigh the necessity for obtaining convictions in sex offense cases.

Any revision of sex offender laws must also repeal much of the sexual psychopath legislation that is presently in force. These laws were passed to provide a means for dealing with dangerous, repetitive, mentally abnormal sex offenders. Unfortunately, the vagueness of the definition of sexual psychopaths contained in these statutes has obscured this basic underlying purpose. There are large numbers of sex offenders who engage in compulsive, repetitive sexual acts, which may be crimes, who may be mentally abnormal, but who are not dangerous. The transvestite, the exhibitionist, the frotteur, the homosexual who masturbates another either in the privacy of his bedroom or in a public toilet, the "peeping tom"-are typical of large numbers of sex offenders who are threatened with long-term incarceration by present sexual psychopath legislation. And what is even worse is that such legislation has not usually been implemented by facilities for treatment. The result is that many nuisance-type, nondangerous sex offenders have been imprisoned for long periods of time, without treatment, in those jurisdictions where such laws have been enforced. This is not to say that the compulsive nondangerous types of sex offenders should be immune from prosecution and punishment; but short sentences or probation are more than adequate to deal with these derelictions, unless better treatment facilities are provided.

In scooping up minor compulsive sex offenders, moreover, sight has been lost of the basic objective of sexual psychopath laws-namely to provide long-term incarceration for dangerous, repetitive sex offenders. Such offenders will be found primarily among those who show a pattern of using children as sexual objects and those whose sex offenses are marked by incidents of sadism and brutality. Such 
individuals can be dealt with just as effectively by traditional methods of law enforcement as under sexual psychopath laws. Obviously, the law should provide long-term prison sentences for dangerous sex offenders-up to life imprisonment, if necessary. It should permit such offenders to be paroled only on a showing of demonstrated improvement and rehabilitation. It should permit such offenders liberty only under the continued supervision of a parole officer and should facilitate their re-incarceration, if they exhibit signs of relapse into the kinds of sexual misbehavior that brought about their incarceration in the first instance.

These are but a few of the many problems that must be met in any revision of sex offender laws. Many have already been considered by the American Law Institute in its Model Penal Code project. ${ }^{30}$ The specific recommendations that have eventuated cannot be analyzed here, but they deserve consideration by those interested in more rational sex offender legislation. The Institute is to be commended for undertaking so controversial a task that characteristically generates far too much heat, stirs entirely too much emotion. Radical departures from existing law in this area conceivably may imperil the acceptance of the Model Penal Code as a whole, and caution might have dictated the deletion of sex offenses from the agenda. Accordingly, it is to the credit of the Institute that it has met the challenge openly and is laying the basis for a more rational code of sex offender laws than is to be found on the statute books of any state.

${ }^{30}$ Model Penal Code art. 207 (Tent. Draft. No. 4, 1955; Tent. Draft. No. 9, 1959). 